\title{
DNA Content of Germinating Spores, Individual Hyphal Cells and Resting Structure Cells of Verticillium spp. Measured by Microdensitometry
}

\author{
By MILTON A. TYPAS ${ }^{1 *}$ AND JAMES B. HEALE 2 \\ ${ }^{1}$ Biology Department, University of Athens, Panepistemiopolis, Kouponia \\ TT 621, Athens, Greece \\ ${ }^{2}$ Biology Department, Queen Elizabeth College, London $W 87 \mathrm{AH}$
}

(Received 3 March 1980)

\begin{abstract}
Using microdensitometry, the cell cycle was investigated in large populations (500) of Feulgen-stained nuclei in conidia, hyphae and resting structures of various strains (all haploid) of Verticillium albo-atrum and $V$. dahliae as well as a stable diploid strain, $V$. dahliae var. longisporum. When uninucleate conidia, harvested from $3 \mathrm{~d}$ Roux bottle agar cultures, were incubated in stationary liquid complete medium at $24{ }^{\circ} \mathrm{C}$ in the dark, they exhibited partial synchrony for germ-tube emergence $(50 \%$ emergent at about $7 \mathrm{~h}$, reaching $95 \%$ at 10 to $12 \mathrm{~h}$ ), DNA replication $(50 \%$ increase at about $7.5 \mathrm{~h})$ and mitosis $(50 \%$ at about $10 \mathrm{~h}$, reaching $95 \%$ at $12 \mathrm{~h}$ ); the second nuclear division occurred at 21 to $24 \mathrm{~h}$. Significant amounts of DNA replication were not detected until $6 \mathrm{~h}$; maximum levels, i.e. a doubling of DNA content (in nuclei not yet divided), occurred at $10 \mathrm{~h}$. There was a $3 \mathrm{~h}$ G1 phase between the first and second nuclear divisions; the S and G2 phases were estimated at about 30 and $90 \mathrm{~min}$ duration, respectively. The absolute DNA content per nucleus for ungerminated conidia of one strain of $V$. dahliae was found to be 0.025 to $0.030 \mathrm{pg}$. In growing hyphae, only the apical cell(s) contained two or more nuclei; DNA levels approximated to those for ungerminated conidia (G1) but a small number of nuclei had begun the $\mathrm{S}$ phase. In hyphal tip regions comprising up to 10 cells, a synchronous nuclear division was observed, and nuclei in the apical cells often had higher DNA values than other nuclei in the same hypha. Cells of young microsclerotia (6 to $8 \mathrm{~d}$-old) of $V$. dahliae and resting mycelium ( 9 to $12 \mathrm{~d}$-old) of $V$. albo-atrum were haploid and uninucleate with a small minority of the nuclei in the $\mathrm{S}$ phase; no evidence for diploidy or endopolyploidy was found at these sampling levels.
\end{abstract}

\section{INTRODUCTION}

Despite a number of recent studies on the cell cycle in the fungi involving investigation of the synthesis of nucleic acids and nuclear division, relatively little work has been done in this field and no attention has been focused on the imperfect fungus Verticillium. In the uninucleate cells of eukaryote organisms, mitosis and cell division are coordinated both in time and position. In Aspergillus nidulans, a fungus genetically similar (apart from its perfect stage) to Verticillium, nuclear division (Robinow \& Caten, 1969; Weijer \& Weisberg, 1966; Rosenberger \& Kessel, 1967) and DNA synthesis (Kessel \& Rosenberger, 1968; Bainbridge, 1971) are normally synchronized, or at least partially synchronized, when the fungus is growing on a rich medium; nuclear divisions are followed by the formation of a series of septae (Clutterbuck, 1970; Bainbridge, 1976). The timing of nuclear division during germination has been studied in A. nidulans and Fusarium oxysporum (Bainbridge, 1971; Kumari et al., 1975). 
The spores of Verticillium species are predominantly haploid and uninucleate and can be obtained in large numbers; their size is a convenient criterion for reliably establishing the level of ploidy (Typas \& Heale, 1977). The hyphae of Verticillium species are septate with cross-walls appearing at almost irregular intervals (although regular septation can occur, particularly in the case of resting mycelium of $V$. albo-atrum), and each septum has a pore in the centre through which the cytoplasm can flow readily (Typas \& Heale, 1979). All the cells of growing hyphae are normally uninucleate, apart from the apical cell which is usually binucleate and, rarely, multinucleate. Thus, this fungus is a favourable organism for timing DNA synthesis in germinating spores, growing hyphae and resting structures. The inheritance of darkly pigmented resting structures (resting mycelium for $V$. albo-atrum and microsclerotia for $V$. dahliae; Heale \& Isaac, 1965) has been shown to be due primarily to cytoplasmic factors (Heale, 1966; Typas \& Heale, 1976b, 1978). However, Tolmsoff (1972, 1973) has proposed that there is 'a transition from a haploid to a diploid state within enlarged hyphae and swollen conidia to produce black resting structures ...., i.e. microsclerotia in the strains of $V$. dahliae which he used.

A cytological investigation of $V$. albo-atrum (Heale et al., 1968), using Giemsa, Feulgen and acid fuchsin staining, revealed detailed aspects of nuclear division in conidia and hyphae of this fungus, including the nucleolus and the development during chromosome separation (anaphase) of a rapidly elongating spindle fibre originating from a centriolar body in early division (prophase); the spindle fibre was only detected in hyphae. Ringed constellations of chromosome bodies joined by very thin Feulgen-positive (but more strongly Giemsapositive) threads, almost beyond the resolution of the light microscope, were faintly discernible during nuclear division in germinating conidia, and divisional figures with a marked bilateral symmetry were thought to represent actual separation. Double-stranded nuclear filaments were often seen in hyphae, but acid fuchsin-positive spindle fibres (a true indication of nuclear division) were encountered in less than 1 per 100 nuclei examined, and invariably in hyphal tip regions. Counts of chromosome bodies suggested a probable haploid number of $\mathrm{n}=4$, although nuclei in which four large and one small set of apparently paired Giemsapositive bodies were also observed.

More recent genetic studies (Typas \& Heale, 1978) involving analysis of recombinants in heterozygous diploids through the parasexual cycle indicated that there are four large and one small linkage groups both in $V$. albo-atrum and $V$. dahliae; therefore, it seems more likely that $\mathrm{n}=5$.

In recent years, microspectrophotometry in association with the Feulgen stain has been extensively used as a method for determining amounts of DNA in individual cell nuclei (Yemma \& Therrien, 1972; Cooke \& Dee, 1974; Therrien \& Yemma, 1974, 1975; Haskins \& Therrien, 1978).

The present work was undertaken to study DNA synthesis and nuclear division during spore germination and to investigate the possibility of changes in ploidy levels being associated with resting structure formation in Verticillium species.

\section{METHODS}

Organisms. Darkly-pigmented $\left(\mathrm{Hyl}^{+}\right)$and hyaline strains (Hyl) of both Verticillium albo-atrum (isolated from potato, U.K.) and Verticillium dahliae (isolated from pepper, U.S.A.), as well as brown (Brm) and albino (Alm) microsclerotia-forming mutants of $V$. dahliae (a defoliating strain isolated from cotton, kindly provided by Professor A. A. Bell, National Cotton Pathology Research Laboratory, Texas, U.S.A.), were used in this study. Verticillium dahliae var. longisporum, a naturally occurring diploid (Ingram, 1968), served as a reference for ploidy level determinations. All strains of Verticillium used here were prototrophic (wildtype) with respect to growth requirements.

Medium. The complete medium (CM) used was Czapek-Dox agar with the addition of casein hydrolysate, yeast extract, peptone and malt extract (each at $2 \mathrm{~g} \mathrm{I}^{-1}$ ) and containing $2 \%(\mathrm{w} / \mathrm{v})$ 'Japanese' agar.

Preparation of material for microdensitometry. All cultures were incubated in the dark at $24{ }^{\circ} \mathrm{C}$. 
(i) Conidia. Spore suspensions to be used as inocula were obtained by washing off the surface of $3 \mathrm{~d}$ parent Petri dish cultures using $10 \mathrm{ml}$ sterile $0.2 \mathrm{M}$-sucrose solution (Typas \& Heale, 1976a), and these were then used to 'seed' the entire surface of Roux bottle agar cultures. The Roux bottle cultures developed confluently during $3 \mathrm{~d}$ incubation and produced a larger and more uniform population of conidia with respect to age and size, resulting in a good degree of synchrony when germinated, compared with results for conidia from conventional Petri dish cultures developing sequentially on centrally inoculated medium (Heale et al., 1968). After $3 \mathrm{~d}$, spore suspensions for incubation studies were washed off the surface of the Roux bottle cultures, again using sterile $0.2 \mathrm{M}$-sucrose, and transferred to $250 \mathrm{ml}$ Erlenmeyer flasks containing $40 \mathrm{ml}$ stationary sterile liquid CM; these cultures were sampled at hourly intervals as shown in Table 1 . All spore samples for microdensitometry were removed under aseptic conditions; the spores were collected on a membrane filter (Oxoid) and resuspended in $0 \cdot 2 \mathrm{M}$-sucrose solution. The suspensions were then centrifuged for $5 \mathrm{~min}$ at $6000 \mathrm{~g}$ and the pellets were ready for fixation and staining.

Germ-tube emergence was assessed as described by Bainbridge (1971) for Aspergillus nidulans and was recorded when the length of the germ-tube was equal to half the diameter of the spore. In each sample 500 spores were counted, to avoid errors caused by the greater standard deviation at lower levels of spore germination.

Young growing hyphae, resting mycelium and microsclerotia in the various isolates used were obtained by the method of Robinow \& Caten (1969) with slight modifications.

(ii) Young growing hyphae. Conidia were spread on sheets of cellophane (P.T. 300) or opened-out dialysis tubing placed on the surface of thin agar films of CM and allowed to germinate. In later tests, conidia were placed between two sheets of dialysis tubing on the surface of thin agar films. Both the cellophane and dialysis tubing were pretreated with ethyl alcohol and sterilized by boiling in water (Heale et al., 1968).

(iii) Resting structures. Young resting structures were obtained from 6 to $8 \mathrm{~d}$ stationary liquid CM cultures of $V$. dahliae and 9 to $12 \mathrm{~d}$ cultures of $V$. albo-atrum which had been inoculated with conidial suspensions taken from $3 \mathrm{~d}$ Roux bottle cultures. Drops containing young resting mycelium (10 to 30 differentiated cells) or microsclerotia ( 5 to 15 differentiated cells) were placed on coverslips and allowed to dry on the bench or in a $35^{\circ} \mathrm{C}$ incubator for 10 to $15 \mathrm{~min}$.

Fixation and Feulgen staining. Fixation throughout was in freshly prepared Helly's solution. The methods of Heale et al. (1968) were followed for fixation and staining of germinating conidia. Growing mycelium, resting mycelium and microsclerotia on cellulose sheets or coverslips were transferred face down on to a dish with fixative. After $10 \mathrm{~min}$ they were rinsed several times with $70 \%$ alcohol, passed directly into $1 \mathrm{M}-\mathrm{HCl}$ at $60{ }^{\circ} \mathrm{C}$ and hydrolysed for 10 to $12 \mathrm{~min}$. All fixed specimens were subsequently transferred to Feulgen stain for 2 to $3 \mathrm{~h}$, rinsed several times with sterile distilled water and then mounted in Euparal. The hydrolysis time was found to be very critical for the subsequent staining of resting structures.

DNA content measurements. A Vickers M86 scanning microdensitometer was used which minimized the errors which can arise when the material over the area measured is not uniform. The integrated density of Feulgen-stained nuclei (approximately $1 \mu \mathrm{m}$ diam. for the haploid cells; Typas \& Heale, 1977) was calculated in arbitrary units.

Measurements for individual nuclei were repeated several times and a mean value was established; a calibration in absolute units of DNA was also performed in one case when nuclei of known DNA content (erythrocyte and hepatic nuclei of carp) were treated together with the nuclei of a $V$. dahliae strain.

\section{RESULTS}

Germ-tube emergence, nuclear division and DNA content per nucleus for germinating conidia

Germ-tube emergence showed partial synchrony and was detected after $4 \mathrm{~h}$ incubation. Germination proceeded rapidly, reaching a maximum value of approximately $95 \%$ conidia with germ-tubes after 10 to $12 \mathrm{~h} ; 50 \%$ germination occurred at about $7 \mathrm{~h}$ (Table 1). Ungerminated conidia of all strains were invariably found to contain one spherical, uniformly stained, centrally placed nucleus. The appearance of the nucleus did not change appreciably until the first signs of impending division were evident when a more granular, irregular shape developed in which ring-like arrangements of several dark staining bodies (chromosomes) were often visible (Heale et al., 1968). The nuclei remained undivided for at least $6 \mathrm{~h}$ following incubation, although a considerable increase in the size of conidia occurred during this period. The first conidia with two daughter nuclei were observed at $7 \mathrm{~h}$, and the $50 \%$ value for the population occurred soon after $10 \mathrm{~h}$; most (about $95 \%$ ) of the germinating conidia 
Table 1. Germ-tube formation, nuclear number and mean relative DNA values per nucleus during spore germination of darkly pigmented, haploid strains $\left(\mathrm{Hyl}^{+}\right)$of $\mathrm{V}$. albo-atrum (I) and $V$. dahliae (II)

A sample of 500 conidia was examined at each time. Conidia in which the first nuclear division had occurred were excluded from the results during the first $12 \mathrm{~h}$ of germination.

\begin{tabular}{|c|c|c|c|c|c|c|}
\hline \multirow{2}{*}{$\begin{array}{l}\text { Time } \\
\text { (h) }\end{array}$} & \multicolumn{2}{|c|}{$\begin{array}{c}\text { Germ-tube } \\
\text { emergence }(\%)\end{array}$} & \multicolumn{2}{|c|}{$\begin{array}{l}\text { Mean no. } \\
\text { of nuclei }\end{array}$} & \multicolumn{2}{|c|}{$\begin{array}{l}\text { Mean relative DNA } \\
\text { value per nucleus }\end{array}$} \\
\hline & I & II & I & II & I & II \\
\hline 0 & - & - & $1 \cdot 0$ & 1.0 & $68 \cdot 66$ & $67 \cdot 32$ \\
\hline 1 & - & - & 1.0 & 1.0 & $69 \cdot 10$ & $68 \cdot 29$ \\
\hline 2 & - & - & 1.0 & $1 \cdot 0$ & $70 \cdot 03$ & $69 \cdot 97$ \\
\hline 3 & - & $0 \cdot 1$ & $1 \cdot 0$ & $1 \cdot 0$ & $71 \cdot 16$ & $72 \cdot 62$ \\
\hline 4 & $4 \cdot 1$ & $4 \cdot 9$ & 1.0 & $1 \cdot 0$ & $71 \cdot 98$ & $72 \cdot 73$ \\
\hline 5 & $12 \cdot 5$ & $15 \cdot 1$ & 1.0 & 1.0 & $72 \cdot 27$ & $73 \cdot 06$ \\
\hline 6 & $27 \cdot 2$ & $32 \cdot 5$ & 1.0 & 1.0 & $82 \cdot 83$ & $82 \cdot 60$ \\
\hline 7 & 48.4 & $55 \cdot 6$ & 1.08 & 1.02 & 95.89 & $95 \cdot 24$ \\
\hline 8 & $70 \cdot 0$ & $77 \cdot 8$ & $1 \cdot 17$ & $1 \cdot 14$ & $111 \cdot 44$ & $110 \cdot 13$ \\
\hline 9 & $85 \cdot 1$ & $92 \cdot 3$ & $1 \cdot 33$ & $1 \cdot 30$ & $124 \cdot 20$ & $121 \cdot 16$ \\
\hline 10 & 91.8 & $96 \cdot 4$ & 1.54 & $1 \cdot 48$ & 138.98 & $140 \cdot 82$ \\
\hline 11 & $93 \cdot 4$ & $98 \cdot 0$ & $1 \cdot 70$ & 1.67 & $139 \cdot 17$ & $142 \cdot 15$ \\
\hline 12 & $95 \cdot 3$ & $98 \cdot 6$ & 1.94 & 1.89 & $139 \cdot 30$ & 143.02 \\
\hline $12^{*}$ & - & - & - & - & $75 \cdot 18$ & $74.83^{*}$ \\
\hline $15^{*}$ & $96 \cdot 0$ & 98.9 & $2 \cdot 21$ & $2 \cdot 10$ & $76.09^{*}$ & $75 \cdot 51^{*}$ \\
\hline $18^{*}$ & $96 \cdot 8$ & $99 \cdot 0$ & $2 \cdot 75$ & $2 \cdot 69$ & $113 \cdot 78^{*}$ & $114 \cdot 33^{*}$ \\
\hline $21^{*}$ & $97 \cdot 3$ & $99 \cdot 1$ & 3.87 & $3 \cdot 68$ & $139.06^{*}$ & $140 \cdot 97^{*}$ \\
\hline $24^{*}$ & 98.5 & 99.0 & $4 \cdot 46$ & $4 \cdot 39$ & $140 \cdot 12^{*}$ & $142 \cdot 24^{*}$ \\
\hline
\end{tabular}

* A set of measurements where conidia in which the first nuclear division had occurred were also included.

had completed the first division by $12 \mathrm{~h}$ (Table 1 ) and the second division followed between 21 and $24 \mathrm{~h}$.

The changes in relative DNA content per nucleus in a population of 500 germinating spores for representative strains are shown in Fig. 1. There were no significant differences in the DNA content at a similar stage in the cell cycle between any of the various strains of $V$. albo-atrum and $V$. dahliae tested, although slightly higher values were sometimes obtained for darkly pigmented $\left(\mathrm{Hyl}^{+}\right)$as compared with hyaline (Hyl) strains. In the case of $V$. dahliae var. longisporum, a stable diploid strain (Ingram, 1968), the values obtained were approximately twice those for the germinating haploid strains, as predicted. Comparing the results in Fig. 1 $(a)$ and $(b)$ for ungerminated haploid conidia of $V$. dahliae and ungerminated diploid conidia of $V$. dahliae var. longisporum, respectively, it was possible to establish arbitrary limits for the $\mathrm{G} 1 / \mathrm{S}$ phase 'boundary' as well as for the $\mathrm{S} / \mathrm{G} 2$ 'boundary', i.e. 90 and 120 units, respectively. From such arbitrary values we have calculated the percentages of the germinating population of the haploid spores in the various cell cycle phases at a particular sampling time. Using this procedure for $V$. dahliae (Fig. $1 a$ ) the approximate percentage of $\mathrm{S}$ nuclei was $10 \%$ at $3 \mathrm{~h}, 20 \%$ at $6 \mathrm{~h}$ and $20 \%$ at $9 \mathrm{~h}$; similarly, the percentage of $\mathrm{G} 2$ nuclei was about $1 \%$ at $3 \mathrm{~h}, 7 \%$ at $6 \mathrm{~h}$ and $66 \%$ at $9 \mathrm{~h}$; the corresponding values calculated for $V$. albo-atrum (Fig. $1 c$ ) were S phase: about $12 \%$ at $3 \mathrm{~h}, 24 \%$ at $6 \mathrm{~h}, 13 \%$ at $9 \mathrm{~h} ; \mathrm{G} 2$ phase: $<1 \%$ at $3 \mathrm{~h}, 6 \%$ at $6 \mathrm{~h}, 73 \%$ at $9 \mathrm{~h}$.

Although a small component of the population had begun the $\mathrm{S}$ phase within $3 \mathrm{~h}$ incubation, the mean DNA content per nucleus for the whole population of 500 sampled nuclei (Fig. 2) did not show a significant increase until the $6 \mathrm{~h}$ period. This mean value for the population increased to a plateau at about $10 \mathrm{~h}$ when it was almost exactly twice that for the ungerminated spores. The doubling of the mean value between 6 and $10 \mathrm{~h}$ showed that the majority of the nuclei in the population underwent the $\mathrm{S}$ phase within this period and is indicative of the extent of synchrony exhibited. 

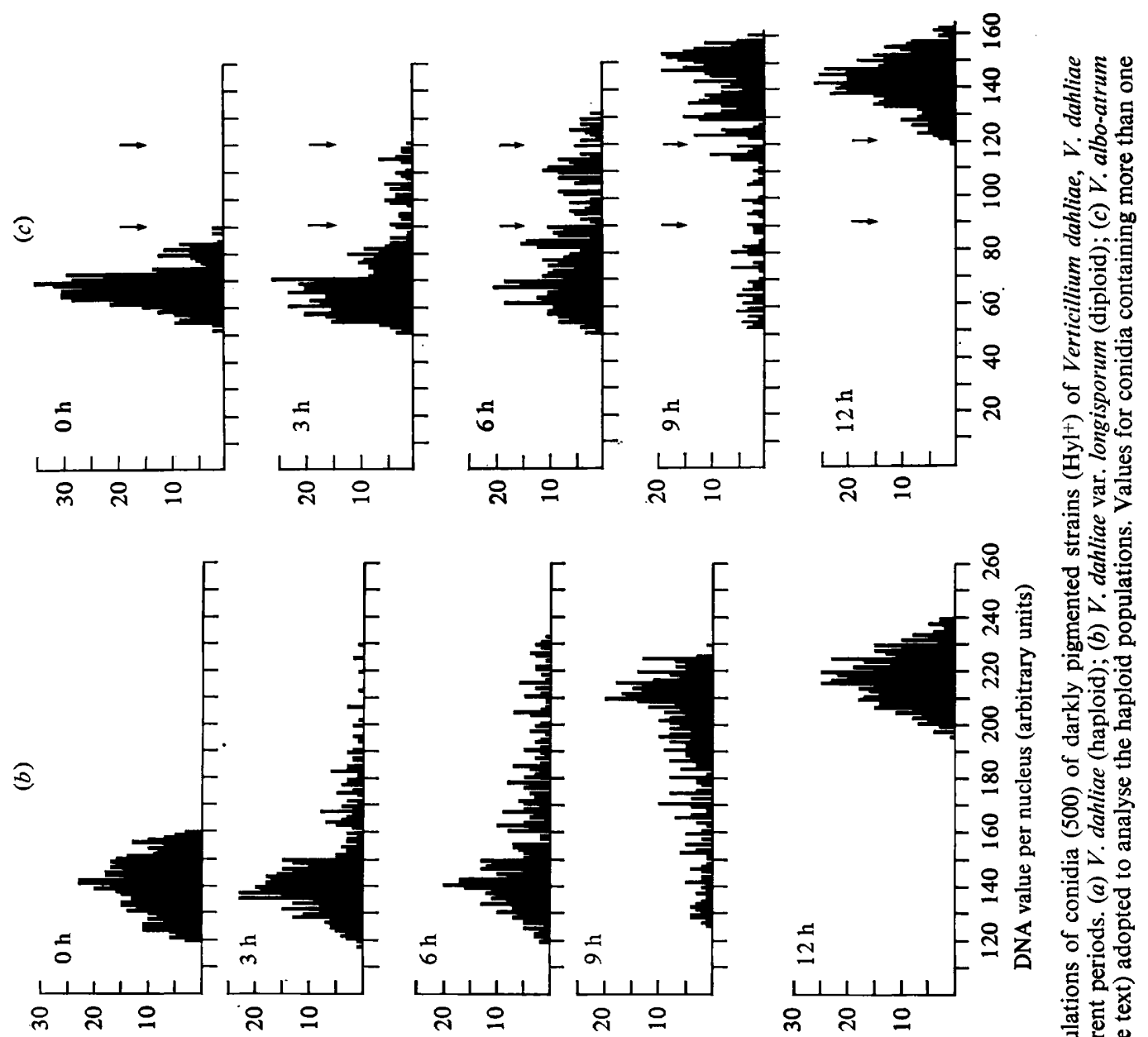

预芯

호음

总官

응

立语

주응 흥

흠 量

돌

옹

융종

포

을

过

氙灾

薦

过 岕

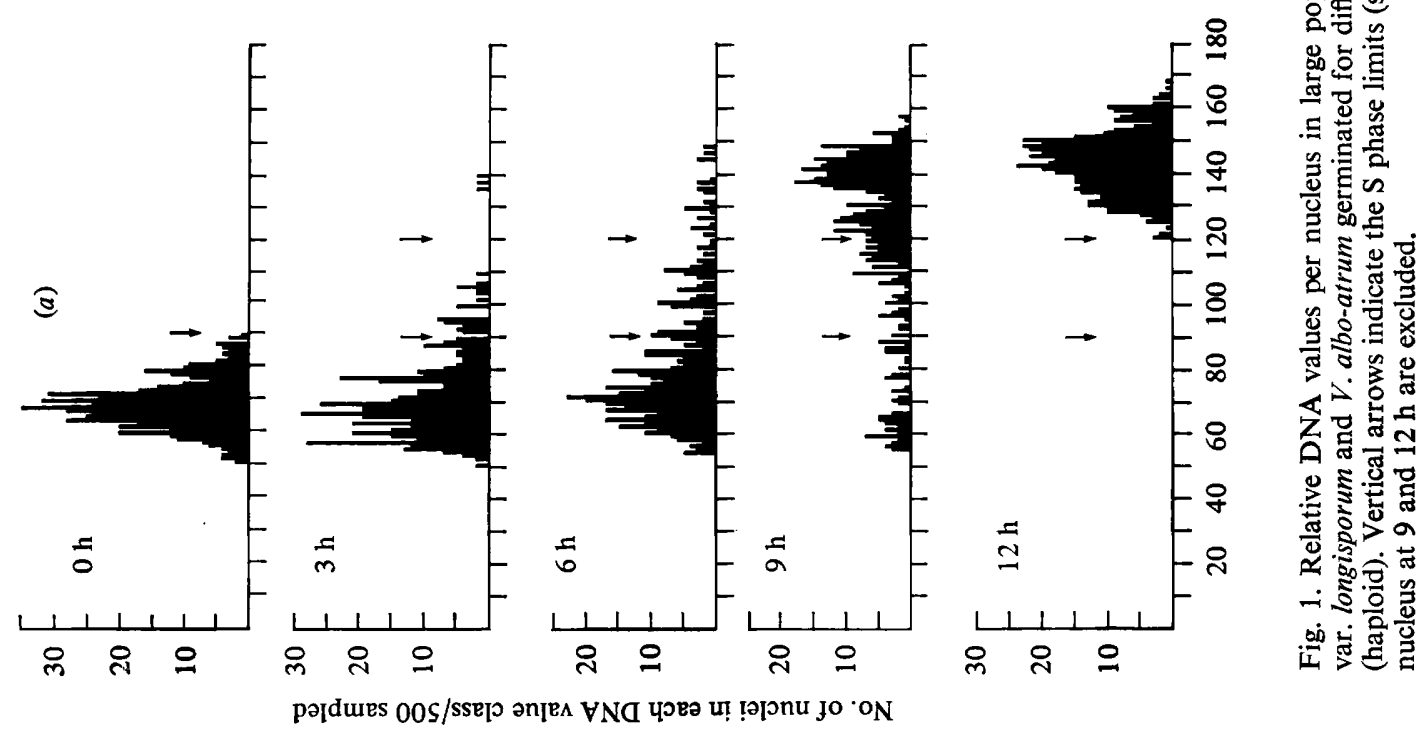



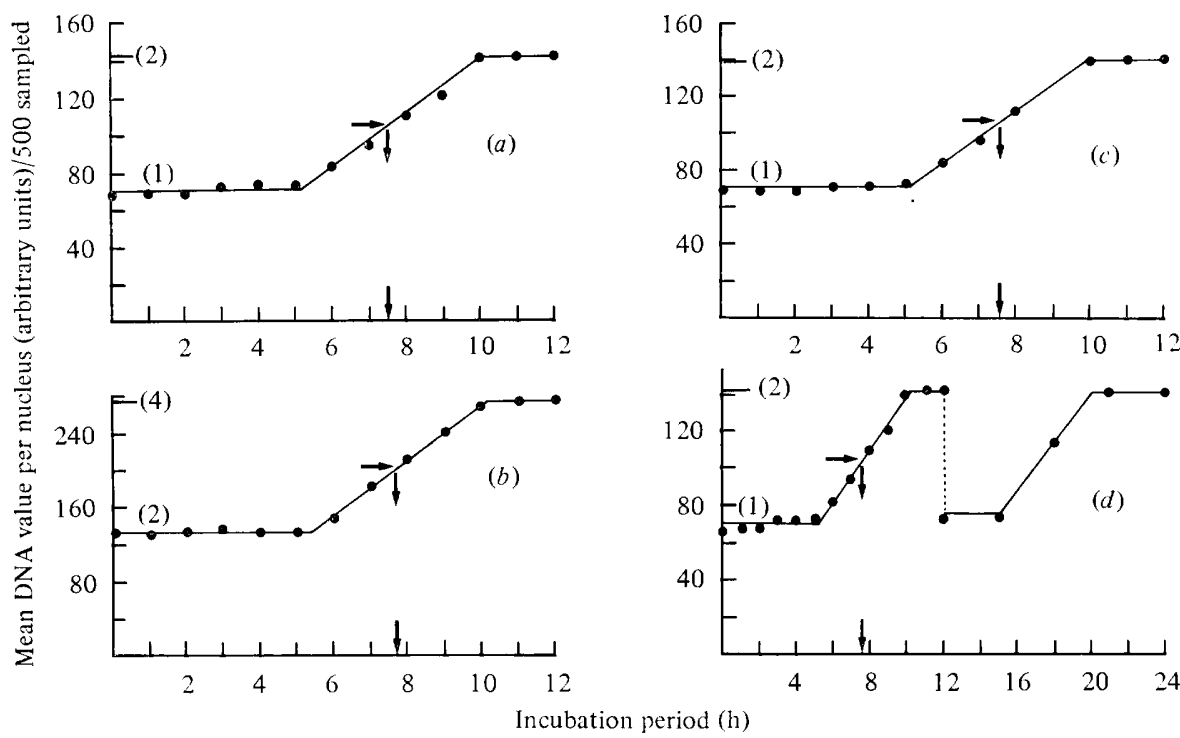

Fig. 2. Mean relative DNA values for large populations of germinating conidia (500) of darkly pigmented strains $\left(\mathrm{Hyl}^{+}\right.$) of $V$. dahliae, $V$. dahliae var. longisporum and $V$. albo-atrum. (a) $V$. dahliae (haploid); (b) V. dahliae var. longisporum (diploid); (c) V. albo-atrum (haploid); (d) V. dahliae (haploid). In $(a, b, c)$ values for conidia containing more than one nucleus are excluded; in $(d)$ the DNA value for conidial nuclei which have undergone division is shown at periods from 12 to $24 \mathrm{~h}$ for the same strain of $V$. dahliae as shown in $(a)$. Numbers in parentheses on the vertical axis denote the doubling of DNA values in the cell cycle. Arrows indicate the time at which the DNA value per nucleus has increased by $50 \%$.

When two sets of measurements were made at $12 \mathrm{~h}$ (Fig. $2 d$ ) - excluding and including the great majority of randomly sampled conidia in the population which had completed the first division (two daughter nuclei were present) - the mean value for the latter was only slightly greater than that for ungerminated conidia (Fig. $2 a$ ). There was a relatively short $\mathrm{G} 1$ phase $(3 \mathrm{~h})$ between the first and second nuclear divisions as compared with the period prior to first division $(5 \mathrm{~h})$ which included a lag phase, and this was therefore estimated to be about $2 \mathrm{~h}$. Heale et al. (1968) also reported a period of $2 \mathrm{~h}$ before any change occurred in the appearance of the compact darkly staining resting nucleus of incubated ungerminated conidia.

The close agreement of the results in Fig. 2 for $V$. albo-atrum and $V$. dahliae also permits a generalized calculation of the time at which $50 \%$ (i.e. $1.5 \mathrm{n}$ ) of the DNA of the population had been replicated, i.e. 7 to $8 \mathrm{~h}$ after incubation. The timing of DNA synthesis in populations of the diploid $V$. dahliae var. longisporum strain (Fig. $2 b$ ) was very similar to that shown for haploid strains of $V$. dahliae (Fig. $2 a$ ) and $V$. albo-atrum (Fig. $2 c$ ).

A calculation of the absolute DNA content per nucleus for ungerminated conidia of the $V$. dahliae $\left(\mathrm{Hyl}^{+}\right)$strain gave a value of 0.025 to $0.030 \mathrm{pg}$.

\section{$D N A$ content of growing hyphae and resting structures}

In growing hyphae, nuclei were located midway between the tip and the first septum, or approximately midway between two septa in all the strains investigated. Most cells were uninucleate, although infrequently cells which apparently contained no nuclei were also observed. The majority of nuclei were spherical and densely staining; nuclei interpreted as undergoing stages in division (Heale et al., 1968) were much less compact and frequently showed as an indistinct arrangement of Feulgen-positive minute bodies or granules which probably represented chromosomes. Only the apical cell(s) contained two nuclei (sometimes 

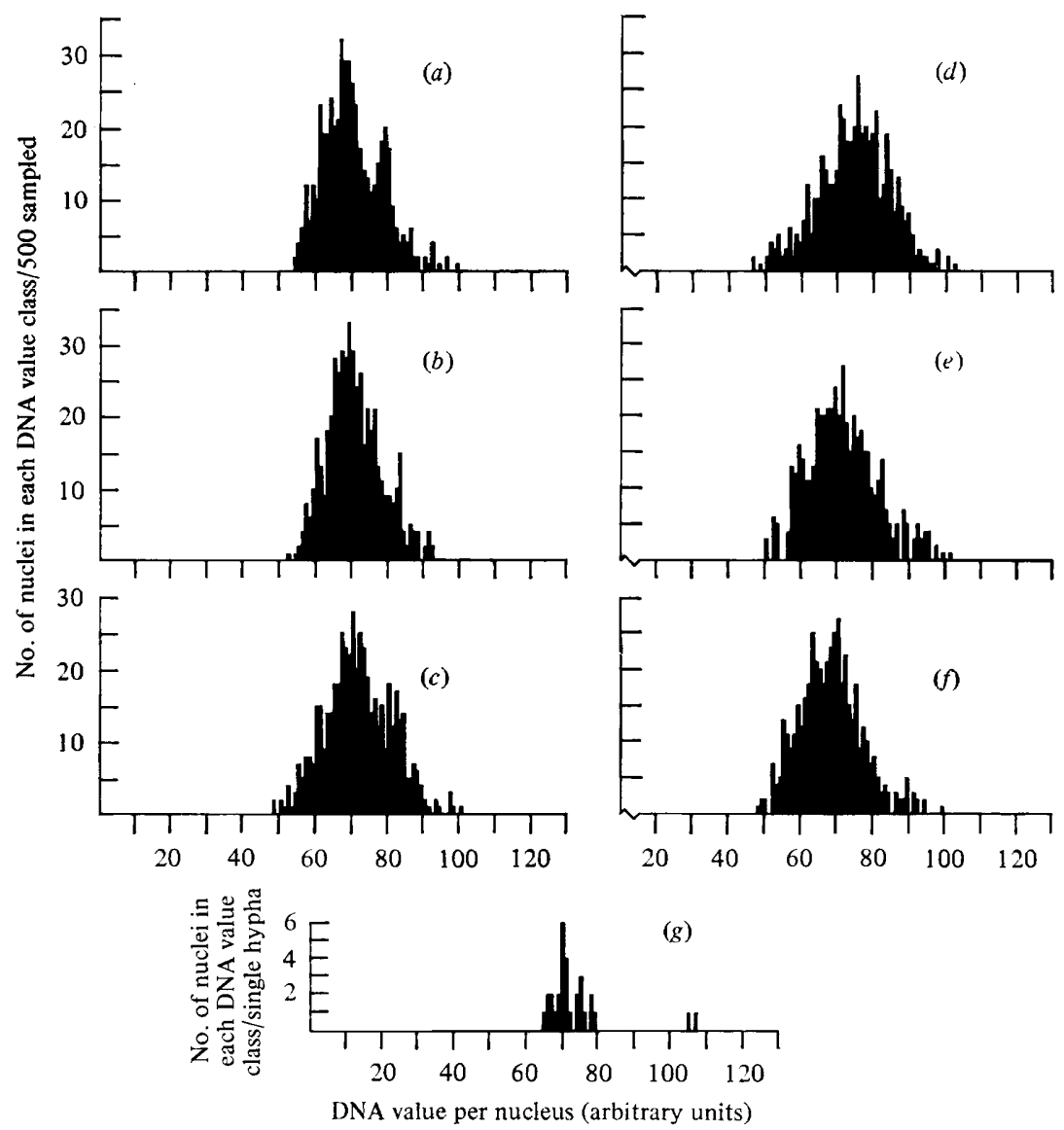

Fig. 3. Relative DNA values per nucleus for large populations of nuclei (500, except $g$ ) in young growing hyphae of various wild-type and mutant or variant strains of $V$.dahliae and $V$. albo-atrum. $(a, b, c, d) V$. dahliae: (a) darkly pigmented wild-type $\left(\mathrm{Hyl}^{+}\right)$producing black microsclerotia; (b) stable hyaline variant (Hyl), microsclerotia absent; (c) a mutant strain producing albino microsclerotia (Alm); $(d)$ a mutant strain producing brown microsclerotia $(\mathrm{Brm}) .(e, f) \mathrm{V}$, albo-atrum: (e) darkly pigmented wild-type $\left(\mathrm{Hyl}^{+}\right)$producing black resting mycelium; $(f)$ stable hyaline variant (Hyl), resting mycelium absent. $(g)$ This shows results for a small population of 30 nuclei within a single hypha, using the same strain of $V$. dahliae as in $(a)$. Note that since 3 to $4 \mathrm{~d}$ cultures were used throughout no resting structures had begun to develop.

three to four and, very rarely, up to ten) arranged close together but along the axis of the hypha.

The DNA content per nucleus for 500 nuclei estimated from many different 3 to 4 d-old growing hyphae are shown in Fig. 3( $a$ to $f)$; the results were similar to the values obtained for ungerminated conidia, but a larger number of nuclei with high DNA values (i.e. above the G1 range) were recorded. As found previously, the values were very similar for all the strains tested.

The walls of resting mycelium and microsclerotia unfortunately had some affinity for the basic fuchsin stain, unlike the walls of both hyaline strains and conidia from all strains. The staining of nuclei in such developing resting structures, without actually staining their cell walls (so that it did not interfere with DNA estimation), was therefore difficult, but this was overcome by altering the hydrolysis times and by selecting young stages in the developmental sequence, i.e. before melanization was completed. Individual cells of both types of resting structure were uninucleate, the nucleus being small, spherical and densely stained. In microsclerotial cells of $V$. dahliae, the nucleus was invariably centrally placed, whereas in the 

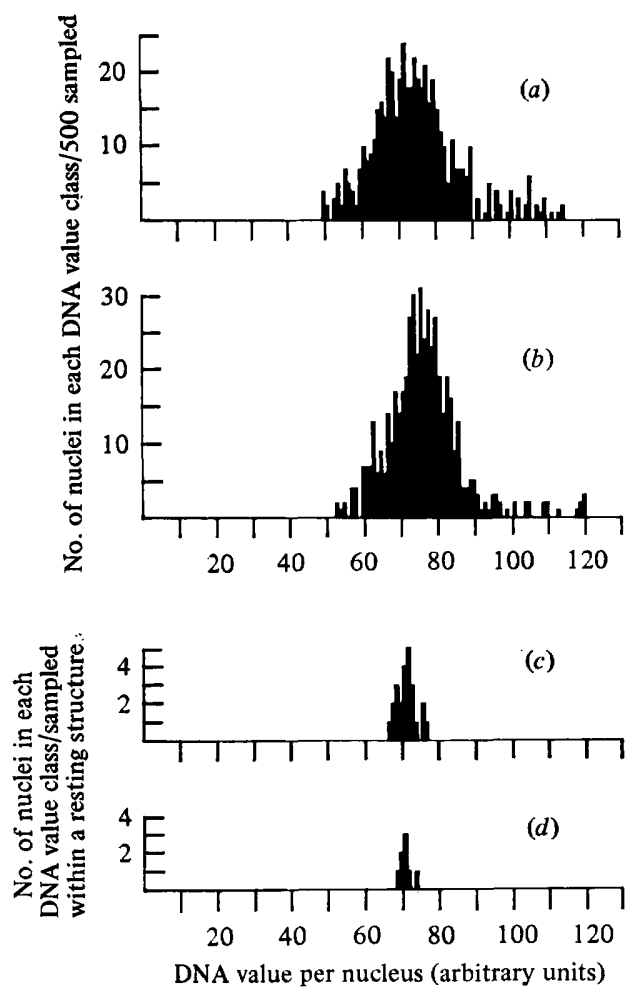

Fig. 4. Relative DNA values per nucleus for populations of nuclei in cells of developing resting structures of wild-type strains $\left(\mathrm{Hyl}^{+}\right)$of $V$. dahliae and $V$. albo-atrum. In $(a)$ and $(b)$ data are presented for large populations of nuclei (500) chosen at random from microsclerotial and resting mycelium cells, respectively. In $(c)$ and $(d)$ data are shown for a single resting mycelium strand containing 24 cells and the same number of nuclei, and a single young microsclerotium containing 10 cells and 8 nuclei, respectively. (a) V. dahliae $\left(\mathrm{Hyl}^{+}\right) ;\left(\right.$b) V. albo-atrum $\left(\mathrm{Hyl}^{+}\right)$; (c) V. albo-atrum $\left(\mathrm{Hyl}^{+}\right) ;(d) V$. dahliae $\left(\mathrm{Hyl}^{+}\right)$. Young stages in development of the resting structures were obtained by using cultures of $V$. dahliae at 6 to $8 \mathrm{~d}$ and those of $V$. albo-atrum at 9 to $12 \mathrm{~d}$.

resting mycelium of $V$. albo-atrum, it was found either close to the transverse septum or near to the longitudinal wall. The mean DNA per nucleus values for 500 microsclerotial and resting mycelial cells (Fig. $4 a, b$ ) were similar to those obtained for large populations of hyphal nuclei and ungerminated conidia. However, a small proportion of nuclei in both types of resting structure (more so in microsclerotia where budding occurs) did result in DNA values in excess of the G1 levels found in ungerminated conidia or the majority of hyphal nuclei. These higher DNA values never reached G2 or higher ploidy levels, and can presumably be interpreted as being due to a non-synchronous mitotic cycle in developing resting structure cells.

The distribution of DNA values for nuclei in a single hypha of $V$.dahliae $\left(\mathrm{Hyl}^{+}\right)$is shown in Fig. $3(g)$ and for a single microsclerotium and resting mycelial strand in Fig. 4(c,d). The distribution of DNA values in nuclei studied within single hyphae suggested that the nuclei within the hyphal tip region divided almost synchronously. Synchrony was particularly marked when young hyphae were examined, i.e. up to 10 cells in length; as growth proceeded the degree of synchrony was reduced. Nuclei at or near to the hyphal tip showed higher DNA values than those away from the tip, e.g. in the particular results presented (Fig. $3 g$ ), two of the three nuclei in the terminal cell of the hypha contained $50 \%$ more DNA than the other nuclei in the same hypha. When the values for nuclei of individual resting structures were examined (Fig. $4 c, d$ ) they were found to be similar to those for ungerminated 
conidia or most hyphal nuclei and here evidence of S phases was absent, no doubt due to their relatively low frequency as indicated by the larger population data presented in Fig. 4(a,b).

\section{DISCUSSION}

The use of a scanning microdensitometer proved to be a very convenient method for reliably estimating the DNA amount per nucleus in conidia (germinating and ungerminated), growing hyphae and resting structures of Verticillium species. Relative DNA contents per nucleus for all pigmented ( $\left.\mathrm{Hyl}^{+}, \mathrm{Brm}\right)$ and non-pigmented (Hyl, Alm) strains indicated that there was no significant difference in the amount of genetic material per conidium between the two species or between the variants. Ungerminated conidia, growing hyphae and resting structures appeared to have approximately the same DNA content per nucleus and to be uniformly haploid at the sampling limits used (i.e. 500). Strain $V$. dahliae var. longisporum was the only variant which had twice the DNA content of the other strains of $V$. dahliae (and $V$. albo-atrum), a result which was expected as $V$. dahliae var. longisporum is known to be a naturally occurring diploid (Ingram, 1968; Typas \& Heale, 1977).

The DNA content per nucleus for ungerminated conidia, growing hyphae and resting structures, based upon calibration, varied within the range 0.025 to 0.030 pg per nucleus. This value is very similar to that obtained from estimations using biochemical methods (M. A. Typas, unpublished results) and to values reported for Aspergillus nidulans and Penicillium atrovenetum conidia (Bainbridge, 1971; and Gottlieb \& Van Etten, 1964, 1966, respectively), but is significantly lower than those reported for conidia of Fusarium oxysporum (Maruyama \& Alexander, 1962; Kumari et al., 1975).

In the uninucleate conidia (of similar age - as harvested here from Roux bottle cultures at $3 \mathrm{~d}$ ) of Verticillium species undergoing germination, the nuclei divide, and germ-tubes emerge, in a partially synchronous pattern, division not occurring until the germ-tube is already present. Following division, one of the daughter nuclei quickly migrates down the germ-tube. This partial synchrony is similar to that observed for germinating conidia of $A$. nidulans (Bainbridge, 1971) and $F$. oxysporum (Kumari et al., 1975). A pause in the increase of mean DNA values for populations of germinating conidia, which occurred at $10 \mathrm{~h}$ when the DNA per nucleus had exactly doubled and when the nuclei first began to divide, also suggested partial synchrony in DNA synthesis (Table 1). The observations of MacGarvie \& Isaac (1966), that the lag time between the appearance of the germ-tube and the first nuclear division was constant for any one Verticillium species, support these findings.

In young growing hyphae, consisting of up to 30 cells, nuclear division was confined almost exclusively to hyphal tips, agreeing with earlier cytological observations on the frequency of spindle fibres in acid fuchsin-stained preparations (Heale et al., 1968). As all hyphal cells contained only one nucleus - the only exception being the apical cell(s) - comparison of DNA content per nucleus of cells within the same hypha (Fig. $3 g$ ) provided a direct estimate of the mode of synchrony in nuclear replication and division. Nuclei within individual hyphae appear to divide almost synchronously, a pattern which is apparently widespread among fungi having multinucleate cells (Rees \& Jinks, 1952; Rosenberger \& Kessel, 1967). The fact that individual nuclei within the apical cell, or those approximating to the hyphal tip, often contained larger amounts of DNA (i.e. in excess of G1 levels) is consistent with previous reports for A. nidulans (King \& Alexander, 1969; Clutterbuck, 1969) that nuclear division was first seen at the hyphal tip and passed in a wave from there to the rear of the hypha. We observed a difference in the timing of division in the tips of branched hyphae of Verticillium species as compared to the main hyphal tips, and in some cases nuclear division apparently occurred in two separate waves indicating the breakdown in synchrony that Kessel \& Rosenberger (1968) and Bainbridge (1971) found in poorer medium. It has been suggested (Clutterbuck \& Roper, 1966) that the synchrony of nuclear replication could be a determining factor for establishment of fungal heterokaryons. This, 
providing that optimum conditions are always used, could have a direct application in the maintenance of heterokaryons of Verticillium through synchrony, as Verticillium heterokaryons are highly unstable (Typas \& Heale, 1976b).

The formation of dark resting structures in Verticillium species has been shown to be under cytoplasmic control (Heale, 1966; Typas \& Heale, 1976b, 1978, 1979). However, there are some reports (Tolmsoff, 1972, 1973) which claim that the inheritance of dark resting structures, and in particular microsclerotia, is due to alterations in ploidy levels within these structures. The distribution of DNA content per nucleus in both resting mycelium and microsclerotia obtained here clearly indicates that there are no major differences in the amount of genetic material contained in nuclei within resting structures, other than that consistent with a small proportion of $S$ phase nuclei. If changes in ploidy levels within microsclerotia or resting mycelium had occurred, they clearly should have been detected by these methods. Our observations therefore support the widely accepted concept of these resting structures as dormant haploid phases in the life cycle rather than as structures in which alterations in ploidy occur (Tolmsoff, 1972, 1973). Our sampling procedures were, of course, unlikely to have identified comparatively rare diploid nuclei (e.g. 1/1000 or less) either in resting structures, hyphae or conidia. Unpublished observations (M. A. Typas \& J. B. Heale) suggest that conidia of many strains of Verticillium may indeed have a natural rate of occurrence of homozygous diploidy of $1 / 10000$ to $1 / 1000$.

The bimodal distributions of Feulgen-positive DNA values in a large population of germinating spores of Verticillium species, as presented here, allows us to estimate G1, S and G2 phases in the cell cycle (Howard \& Pelc, 1953). It is known that the S phase is normally characterized by rapid DNA synthesis although a small amount of replication has been shown to continue during the G2 phase (Kihlman \& Hartley, 1967). From our results, the temporal relation between DNA synthesis and germ-tube emergence indicates that the onset of DNA replication occurs prior to, or just after, germ-tube emergence. Based on mean population data, synthesis of DNA was first detected after $5 \mathrm{~h}$ (although a small component of the population entered the $\mathrm{S}$ phase at $3 \mathrm{~h}$; Fig. 1) and significant numbers of nuclear divisions first occurred at $7 \mathrm{~h}$; from this, the sequence of phases S-G2-mitosis therefore takes approximately $2 \mathrm{~h}$. The $\mathrm{S}$ phase duration can be inferred from the results in Figs 1 and 2; DNA values reached the 1.5 value, i.e. the population showed a $50 \%$ increase in the G1 DNA value, between 7 and $8 \mathrm{~h}$, whereas maximum levels, i.e. G2, occurred at $10 \mathrm{~h}$. At 7 to $8 \mathrm{~h}$, the proportion of cells in the population with $\mathrm{S}$ phase nuclei (using arbitrary limits as defined in Results) was about $25 \%$; therefore the length of $\mathrm{S}$ is given by $(25 / 100) \times 2 \mathrm{~h}=30 \mathrm{~min}$, i.e. $50 \%$ longer than that found for $A$. nidulans (Kessel \& Rosenberger, 1968). Assuming that actual division takes only a few minutes, the G2 phase, by difference, is estimated as about $2 \mathrm{~h}-30 \mathrm{~min}=$ about $90 \mathrm{~min}$. As stated previously, the $\mathrm{G} 1$ phase between division and the $\mathrm{S}$ phase prior to the second nuclear division was found to last about $3 \mathrm{~h}$, whereas prior to first division (and including the lag phase) it was about $5 \mathrm{~h}$ in duration. Thus G1 appears to be much longer than G2. This is in contrast both with the situation in Saccharomyces cerevisiae and Blastocladiella emersonii where G1 is very short (Williamson, 1965; and Lovett, 1975, respectively) and in Phycomyces blakesleeanus (Schmit \& Brody, 1976) where some of the nuclei were arrested in the G1 phase and some in the G2 phase. However, it is in general agreement with results for other fungi such as $A$. nidulans (Bainbridge, 1971) and $F$. oxysporum (Kumari et al., 1975).

In all our experiments, optimum conditions of growth and incubation were used as it was initially found that changes in growth conditions affected nuclear replication in a similar manner to that found in A. nidulans (Kessel \& Rosenberger, 1968). The duration of the G1, $\mathrm{S}$ and $\mathrm{G} 2$ phases was very similar for both haploid and diploid strains of $V$. dahliae. This was expected as the nuclear surface area increases with DNA content so that the rate of DNA synthesis is similar in nuclei of different ploidy levels (Alfert \& Das, 1969).

We would like to thank Dr B. W. Bainbridge for useful criticism and advice. 


\section{REFEREN CES}

Alfert, M. \& DaS, N. K. (1969). Evidence for control of the rate of nuclear DNA synthesis by the nuclear membrane in eukaryotic cells. Proceedings of the National Academy of Sciences of the United States of America 63, 123-128.

BAINBRIDGe, B. W. (1971). Macromolecular composition and nuclear division during spore germination in Aspergillus nidulans. Journal of General Microbiology 66, 319-325.

BAINBRIDGE, B. W. (1976). Estimation of the generation time and peripheral growth zone of Aspergillus nidulans and Alternaria solani hyphae from radial growth rates and ranges in apical cell length. Journal of General Microbiology 97, 125-127.

Clutterbuck, A. J. (1969). Cell volume per nucleus in haploid and diploid strains of Aspergillus nidulans. Journal of General Microbiology 55, 291-299.

Clutterbuck, A. J. (1970). Synchronous nuclear division and septation in Aspergillus nidulans. Journal of General Microbiology 60, 133-135.

Clutiterbuck, A. J. \& Roper, J. A. (1966). A direct determination of nuclear distribution in heterokaryons of Aspergillus nidulans. Genetical Research 7, 185-194.

COOKE, D. J. \& DEE, J. (1974). Plasmodium formation without change in nuclear DNA content in Physarum polycephalum. Genetical Research 23, 307-318.

Gottlieb, D. \& Van Etten, J.L. (1964). Biochemical changes during the growth of fungi. I. Nitrogen compounds and carbohydrate changes in Penicillium atrovenetum. Journal of Bacteriology 88, 114-121.

GotTlieb, D. \& VAN ETTEN, J. L. (1966). Changes in fungi with age. I. Chemical composition of Rhizoctonia solani and Sclerotium bataticola. Journal of Bacteriology 91, 161-168.

Haskins, E. F. \& Therrien, C. D. (1978). The nuclear cycle of the myxomycete Echinostelium minutum. I. Cytophotometric analysis of the nuclear DNA content of the amoebal and plasmodial phases. Experimental Mycology 2, 32- 40 .

Heale, J. B. (1966). Heterokaryon synthesis and morphogenesis in Verticillium. Journal of General Microbiology 45, 419-427.

Heale, J. B. \& IsaAC, I. (1965). Environmental factors in the production of dark resting structures in Verticillium albo-atrum, $V$. dahliae and $V$. tricorpus. Transactions of the British Mycological Society 48, 39-50.

Heale, J. B., Gafoor, A. \& Rajasingham, K. C. (1968). Nuclear division in conidia and hyphae of Verticillium albo-atrum. Canadian Journal of Genetics and Cytology 10, 321-340.

Howard, A. \& Pelc, S. R. (1953). Synthesis of DNA in normal and irradiated cells and its relation to chromosome breakage. Heredity 6 (Suppl.), 261.

INGRAM, R. (1968). Verticillium dahliae Kleb. var. longisporum Stark, a stable diploid. Transactions of the British Mycological Society 51, 339-441.
Kessel, M. \& Rosenberger, R. F. (1968). Regulation and timing of deoxyribonucleic acid synthesis in hyphae of Aspergillus nidulans. Journal of Bacteriology 95, 2275-2281.

Kihlman, B. A. \& Hartley, B. (1967). Subchromatid exchanges and the 'folded fiber' model of chromosome structure. Hereditas 57, 289-294.

KInG, S. B. \& AleXANDer, L. J. (1969). Nuclear behavior, septation and hyphal growth of Alternaria solani. American Journal of Botany 56, 249-253.

Kumari, L., Decallone, J. R. \& Meyer, J. A. (1975). Deoxyribonucleic acid metabolism and nuclear division during spore germination in Fusarium oxysporum. Journal of General Microbiology 88, 245-252.

LOVETT, J. (1975). Growth and differentiation of Blastocladiella emersonii: cytodifferentiation and the role of ribonucleic acid and protein synthesis. Bacteriological Reviews 39, 345-404.

MacGarvie, Q. \& IsAaC, I. (1966). Structure and behaviour of the nuclei of Verticillium spp. Transactions of the British Mycological Society 49, 687-693.

Maruyama, Y. \& Alexander, M. (1962). Distribution of protein and nucleic acids in hyphae and microconidia of Fusarium. Archiv. für Microbiologie 41, 401-407.

REES, H. \& JINKS, J. L. (1952). The mechanism of variation in Penicillium heterokaryons. Proceedings of the Royal Society B140, 100-106.

Robinow, C. F. \& CATEN, C. E. (1969). Mitosis in Aspergillus nidulans. Journal of Cell Science 5, 403-431.

Rosenberger, R. F. \& Kessel, M. (1967). Synchrony in nuclear replication in individual hyphae of Aspergillus nidulans. Journal of Bacteriology 94, 1464-1469.

Schmit, J. C. \& Brody, S. (1976). Biochemical genetics of Neurospora crassa conidial germination. Bacteriological Reviews 40, 1-41.

Therrien, C. D. \& Yemma, J. J. (1974). Comparative measurements of nuclear DNA in a heterothallic and a self-fertile isolate of the myxomycete, Didymium iridis. American Journal of Botany 61, 400-404.

Therrien, C. D. \& Yemma, J. J. (1975). Nuclear DNA content and ploidy values in clonallydeveloped plasmodia of the myxomycete Didymium iridis. Caryologia 28, 313-320.

TolmsofF, W. J. (1972). Diploidization and heritable gene repression-depression as a major source for variability in morphology, metabolism and pathogenicity of Verticillium species. Phytopathology 62, 407-413.

Tolmsoff, W. J. (1973). Life cycles of Verticillium species. In Verticillium Wilt of Cotton, Proceedings of a Work Conference, National Cotton Pathology Research Laboratory, College Station, Texas 1971, (ARS-S-19), pp. 20-38.

Typas, M. A. \& Heale, J. B. (1976a). Acriflavineinduced hyaline variants in Verticillium alboatrum and $V$. dahliae. Transactions of the British Mycological Society 66, 15-25. 
Typas, M. A. \& Heale, J. B. (1976b). Heterokaryosis and the role of cytoplasmic inheritance of dark resting structure formation in Verticillium species. Molecular and General Genetics 146, 17-26.

Typas, M. A. \& Heale, J. B. (1977). Analysis of ploidy levels in strains of Verticillium using a Coulter counter. Journal of General Microbiology 101, 177-180.

TYPas, M. A. \& Heale, J. B. (1978). Heterozygous diploid analyses via the parasexual cycle and a cytoplasmic pattern of inheritance in Verticillium species. Genetical Research 31, 131-144.

Typas, M. A. \& Heale, J. B. (1979). Transfer of a cytoplasmic factor by micro-injection in Verti- cillium. Journal of General Microbiology 111, 375-386.

WeIJER, J. \& WeISBERG, S. H. (1966). Karyokinesis of the somatic nucleus of Aspergillus nidulans. I. The juvenile chromosome cycle (Feulgen staining). Canadian Journal of Genetics and Cytology 8, 361-374.

Williamson, D. H. (1965). The timing of DNA synthesis in the cell cycle of Saccharomyces cerevisiae. Journal of Cell Biology 25, 517-528.

YeMMA, J. J. \& THERRIEN, C. D. (1972). Quantitative microspectrophotometry of nuclear DNA in selfing strains of the myxomycete Didymium iridis. American Journal of Botany 59, 828-835. 